〔日農医誌 60巻 5 号 597～601頁 2012. 1〕

\title{
報告：
}

\section{中山間地における高齢者の消化器がんに対する 内服による外来化学療法}

\author{
長谷川 毅*，三 宅 孝*
}

当院は愛知県豊田市北東部を診療圈とする中山間地に位置し，高齢化率が約 $34 \%$ となり 年々増加しつつある。自家用車を持たない高齢者も多く, 病院への交通手段も限られ，週 1, 2 回のコミュニティーバス以外の交通手段しかない地域も多いため検診受診や病院受 診抑制の原因となっている。その結果，消化器がんは進行した状態や切除不能な状態でみ つかることもまれでない。そのため，比較的元気に実生活を送っている高齢者に対しては 進行および切除不能, 再発消化器がんに対して化学療法を考慮すべき症例も時々経験す る。当院では，2005年 4 月から 2010 年 6 月までの約 5 年間に進行，切除不能，再発の消化 器がんに対し開腹術（試験開腹も含む）を行なった70歳以上の高齢者のうち認知症にて充 分なインフォームドコンセントのとれない症例や全身状態の良好でない症例を除いた 25 例 に対し S-1単独療法を行なった。その結果，高齢者に対する $\mathrm{S}-1$ 単独療法は通常の年歯層 への S-1療法を中心とした化学療法や他の化学療法と比べ症例数が少ないため単純に比較 はできないが，疾患によっては比較的良好な結果を得ることができている。そのため当院 では内服である S-1単独療法を高齢者にとって QOL を考えた消化器がんに対する化学療 法のひとつと位置づけ施行している。

\section{(1)中山間地 (2)高齢者 (3)消化器がん (4) $\mathrm{S}-1$ 療法}

\section{緒言}

当院は愛知県豊田市北東部を診療圈とする中 山間地に位置し，診療人口約 2 万人弱で診療圈 の高齢化率は約34\%であり年々増加しつつあ る。また，入院患者の約 $90 \% か ゙ 70$ 歳以上の高齢 者である。外来通院患者の通院の交通手段は自 家用車が主であるが，自家用車をもたない高齢 者も多い。その多くの高齢者にとっては, 地域 によっては病院へのアクセスは病院を中心に運 行される週 1，2 回のコミュニティーバスのみ となる。病院へのアクセスが限られていること

\footnotetext{
* 干444-2351 愛知県豊田市岩神町仲田20 足助病院外科

（受付：2010年11月22日）
}

が検診や病院への受診抑制の一因となってお り, 当院では僻地巡回等にて検診や受診の啓蒙 活動を積極的に行なってきているが, 消化器が 几発見時には進行した状態または切除不能な状 態でみつかることもまれでないため，比較的元 気に実生活を送っている高齢者の進行および切 除不能, 再発消化器がんに対して化学療法を考 慮すべき症例も時々経験する。

\section{方法}

高齢者でも平均余命としては80歳の時点で男 性8.66歳, 女性11.68歳であり，高齢者のうち 農作業に従事している方など比較的元気に実生 活を送っている方には若年者と同じく進行，切 除不能, 再発の消化器がんや乳がんに対して化 学療法を考慮すべき症例もなかにはあると考え 
られる（平成22年 7 月 26 日厚生労働省大臣官房 統計情報部人口動態・保健統計課発表)。

しかし，高齢者には骨髄抑制が起こりやすい などの一般的な副作用の問題のみならず，自家 用車などの自由に移動可能な交通手段を持たな い方が多い。当院のような中山間地においては 病院への交通手段は自宅から坂を下った十数分 離れたところにバス停が存在する週 $1 ， 2$ 回の コミュニティーバスに頼らざるを得ないこと， 雨や冬の積雪などでその限られた交通手段も制 限されることが多々あること，また服薬コンプ ライアンスの観点からも当院では70歳以上の高 齢者に対する外来化学療法の選択肢のひとつと して内服による $\mathrm{S}-1$ 単独療法も行なってきた。 当院で 2005 年 4 月から 2010 年 6 月までの約 5 年間に進行, 切除不能, 再発の消化器がんに対 し開腹術（試験開腹も含む）を行なった70歳以 上の高齢者のうち認知症などにて充分なイン フォームドコンセントのとれない症例や全身状 態の良好でない症例を除いた 25 例に対し内服に よる $\mathrm{S}-1$ 単独療法を行なった。治療開始前に， 病名の告知および化学療法を行なう利点や欠点 以外に，現在の各疾患別のがん治療ガイドライ ンとは異なる場合には S-1単独療法を行なう利 点や欠点をご家族の立ち会いのもとにご本人に 充分なインフォームドコンセントを行ない納得 し承諾を得た上で施行した。

投与方法としては 1 日あたりテガフール・ギ メラシル・オテラシルカリウム配合カプセル剂

（以下 $\mathrm{TS}-1$ ）を年齢，全身状態等も考慮しな がら $80 \mathrm{mg}$ から $120 \mathrm{mg}$ の幅で内服し， 4 週投薬 2 週休薬または 2 週投薬 1 週休薬を 2 回繰り返 し，それを 1 サイクルとし，進行がんに対する 術後補助化学療法としては約 1 年間，その他の 場合は可能な限り継続した（表 1$)$ 。また全例 ではないが，服薬コンプライアンスを高めるた め内服手帳の利用や投薬時の薬剤師からの説 明，内服方法のパンフレット配布だけでなく， 訪問看護の利用，電話での内服確認や来院され ないときの所在確認および定期通院日の連絡も 行なってきた。
結果

S-1単独療法開始時の平均年齢は81.5歳に て，そのうち70歳から75歳未満が10例 (40\%), 75 歳以上 80 歳未満が10例 $(40 \%)$ ，80歳以上が 5 例 (20\%) であった。性別でみると男性18例 $(72 \%)$, 女性 7 例 $(28 \%)$ で男性が約 7 割を占 めた。疾患別の内訳は胃がん11例 $(44 \%)$, 大腸 がん 13 例 $(52 \%) ，$ 膵がん 1 例 $(4 \%)$ であっ た。進行度別では進行がんによる術後補助化学 療法に -1 療法を 1 年間行なった症例は 5 例 $(20 \%)$, 切除不能または非治癒切除に対しては 13例 $(52 \%)$, 再発に対しては 7 例 $(28 \%)$ に 1療法を継続し行なった。TS-1の 1 日投与量は 80mg が23例 (92\%)，100mg が 1 例 ( $4 \%$ ), 120 $\mathrm{mg}$ が 1 例 $(4 \%)$ であった。 $\mathrm{S}-1$ 単独療法時 の投与方法は 4 週投薬 2 週休薬が 3 例 (12\%), 2 週投薬 1 週休薬が22例（88\%）であった。副 作用を認めないものが16例 $(64 \%)$, 副作用と して好中球減少を 7 例（28\%）に認めたが $\mathrm{S}-1$ 単独療法継続は全て可能であった。その他，皮 疹が 1 例 $(4 \%)$, 嘔気と肝機能異常を 1 例 （4\%）に認めた。死亡症例17例のうち生存期 間は平均 16.5 か月にて疾患別の生存期間は胃が んが平均16.3か月，大腸がんが平均16.3か月， 荤がんが 1 例ではあるが20か月であった（表 $1)$ 。

\section{考察}

当院で高齢者に対して化学療法を行なうとき は，農作業に従事している方がほとんどで，な おかつ独居世帯や老夫婦のみの世帯も多いた め，入院加療を好まない方が多い。また外来で 化学療法を行なうときでも，通院回数が少ない などの QOL を損なわないことをご本人および 家族は第一に望まれることが多い。当院では化 学療法を予定している高齢者に対しては，ご本 人だけでなくご家族にも病名の告知および化学 療法の利点や欠点をインフォームドコンセント した上で，施行する化学療法を充分理解および 承諾できる方のみを対象に化学療法を行なって いる。化学療法には各疾患別のがん治療ガイド 
表 1. 当院における術後の S-1療法施行症例

\begin{tabular}{|c|c|c|c|c|c|c|c|}
\hline 症例 & 年齢 & 疾患名 & 投与理由 & 容量 & 投与方法 & 生存期間 & 副作用 \\
\hline 1 & 72 & 大腸がん & 再発 & $80 \mathrm{mg}$ & 2 投 1 休 & 19か月 & なし \\
\hline 2 & 79 & 胃がん & 再発 & $80 \mathrm{mg}$ & 2 投 1 休 & 23か月 & なし \\
\hline 3 & 70 & 胃がん & 再発 & $120 \rightarrow 80 \mathrm{mg}$ & 2 投 1 休 & 15か月 & 皮疹 \\
\hline 4 & 70 & 胃がん & 切除不能 & $80 \mathrm{mg}$ & 4 投 2 休 & 7 か月 & なし \\
\hline 5 & 72 & 胃がん & 非治癒切除 & $80 \mathrm{mg}$ & 2 投 1 休 & 28か月 & 好中球減少 \\
\hline 6 & 81 & 大腸がん & 再発 & $80 \mathrm{mg}$ & 2 投 1 休 & 15か月 & 好中球減少 \\
\hline 7 & 70 & 胃がん & 非治癒切除 & $120 \mathrm{mg}$ & 4 投 2 休 & 11か月 & なし \\
\hline 8 & 80 & 大腸がん & 非治癒切除 & $80 \mathrm{mg}$ & 2 投 1 休 & 12か月 & なし \\
\hline 9 & 71 & 胃がん & 切除不能 & $80 \mathrm{mg}$ & 2 投 1 休 & 18か月 & なし \\
\hline 10 & 81 & 大腸がん & 非治癒切除 & $80 \mathrm{mg}$ & 2 投 1 休 & 6 か月 & なし \\
\hline 11 & 77 & 膵がん & 切除不能 & $80 \mathrm{mg}$ & $\begin{array}{l}2 \text { 投 } 1 \text { 休 } \rightarrow \\
2 \text { 投 } 2 \text { 休 }\end{array}$ & 20か月 & 好中球減少 \\
\hline 12 & 78 & 大腸がん & 非治癒切除 & $80 \mathrm{mg}$ & 2 投 1 休 & 41か月 & なし \\
\hline 13 & 76 & 大腸がん & 補助化学療法 & $100 \mathrm{mg}$ & 4 投 2 休 & - & 好中球減少 \\
\hline 14 & 78 & 胃がん & 補助化学療法 & $80 \mathrm{mg}$ & 2 投 1 休 & - & 好中球減少 \\
\hline 15 & 80 & 大腸がん & 再発 & $80 \mathrm{mg}$ & 2 投 1 休 & 7 か月 & なし \\
\hline 16 & 75 & 大腸がん & 再発 & $80 \mathrm{mg}$ & $\begin{array}{l}2 \text { 投 } 1 \text { 休 } \rightarrow \\
2 \text { 投 } 3 \text { 休 }\end{array}$ & 生存（34か月） & 好中球減少 \\
\hline 17 & 74 & 大腸がん & 補助化学療法 & $80 \mathrm{mg}$ & 2 投 1 休 & - & なし \\
\hline 18 & 76 & 大腸がん & 補助化学療法 & $80 \mathrm{mg}$ & 2 投 1 休 & - & 好中球減少 \\
\hline 19 & 79 & 大腸がん & 非治癒切除 & $80 \mathrm{mg}$ & 2 投 1 休 & 生存（25か月） & なし \\
\hline 20 & 79 & 胃がん & 非治癒切除 & $80 \mathrm{mg}$ & 2 投 1 休 & 生存（12か月） & $\begin{array}{l}\text { 吐気と肝機能 } \\
\text { 異常 }\end{array}$ \\
\hline 21 & 74 & 胃がん & 非治癒切除 & $80 \mathrm{mg}$ & 2 投 1 休 & 13か月 & なし \\
\hline 22 & 83 & 大腸がん & 再発 & $80 \mathrm{mg}$ & 2 投 1 休 & 生存（11か月） & なし \\
\hline 23 & 74 & 大腸がん & 非治癒切除 & $80 \mathrm{mg}$ & 2 投 1 休 & 生存（ 7 か月） & なし \\
\hline 24 & 78 & 胃がん & 非治癒切除 & $80 \mathrm{mg}$ & 2 投 1 休 & 生存（ 5 か月） & なし \\
\hline 25 & 71 & 胃がん & 補助化学療法 & $80 \mathrm{mg}$ & 2 投 1 休 & - & なし \\
\hline
\end{tabular}

ラインに沿って多種多様な方法があるが，高歯 であるため食欲低下や骨髄抑制などの副作用出 現がより危惧されること，当院の通院の交通手 段や天候などの特殊事情（当院を基点に運行さ れるコミュニティーバスは，ある地域のバス停 においては自宅から坂道を徒歩で十数分の距離 にあり，なおかつ週 $1 ， 2$ 回のみにて数時間で 帰りのバスがでることもあるため，例えば外来 での点滴施行時に投与時間も限られることがあ る）があること，またコンプライアンスの観点 からも S-1単独療法をがん治療ガイドラインに のっとった治療のできない症例によっては考慮
することで，当院では高齢者に対する消化器が んの外来化学療法を比較的安全に継続して生活 やQOLを損なわずに行なうことができてい る。また，当院で施行している高齢者に対する $\mathrm{S}-1$ 単独療法は投与量を体重や腎機能などから 算出する基準投与量に基づき投与するようにし ているが，実際には80mg と低容量で施行して いる例がほとんどである。通常の年齢層への $\mathrm{S}$ -1療法や他の化学療法と比べると症例数が少な いため，比較の対象にはできないが，胃がんで は SPIRITS 試験の S $-1+$ Cisplatin の結果を上 回り，大腸がんでは FOLFOX や FOLFIRI よ 
りは下回るものの RPMI 療法と同等の結果は 認めている。再発時もがん治療ガイドラインに 沿った治療が行なえない高齢者の症例に対し治 療を継続でき，ある程度の効果も期待できる QOL を損なわない治療法のひとつとして位置 づけることも可能ではないかと思われる ${ }^{1,2)} 。$

高齢者に対する化学療法の問題点として食思 不振や骨髄抑制の出現しやすさがあると言われ ているが，投与間隔を 4 週投薬 2 週休薬から 2 週投薬 1 週休薬とすることにより副作用も軽減 でき，長期にわたり継続することが可能である 症例もあった。TS-1内服が長期にわたると 2 週投薬 1 週休薬でも好中球減少が認められると きは休薬期間を 2 週間に延長し 2 週投薬 2 週休 薬にすることにより内服を続行することができ た症例もあり，これまでの経験から当院では現 在では，高齢者に対する S-1単独療法は 1 日投 与量 $80 \mathrm{mg}$ で 2 週投薬 1 週休薬を標準投与法と し，骨髄抑制などの副作用出現時には 2 週投薬 2 週休薬と休薬期間を延長し化学療法を継続し ている。また，化学療法中止の条件は Progressive Disease（PD）の状態になったときを基 本としているが，PDの状態となっても無症状 のため化学療法継続を望まれるケースが多く, 実際には痛みや食思不振が増強してきたときや 肝機能異常などの問題がでてきたときにご本人 およびご家族に化学療法継続の欠点を話し，充 分納得してもらった上で中止する症例がほとん どである。

文献を検索すると高齢者に対する TS-1の投 与方法として，多くはガイドライン通りの 4 週 投薬 2 週休薬を基本としているが，当院の方法 に準拠したような 5 日投薬 2 日休薬，2 週投薬 1 週休薬， 2 週投薬 2 週休薬等を症例によって は行なうことで副作用を軽減しつつ効果を維持 しているものも認めた ${ }^{3,4)}$ 。投与量においても 体重や腎機能などから算出した基準投与量から

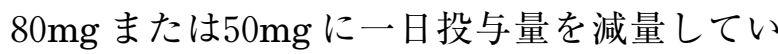
る文献を認めた ${ }^{5)}$ 。

TS-1を基軸とした化学療法では胃がんでは $\mathrm{TS}-1+\mathrm{CDDP}$ ，大腸がんでは TS-1+CPT-11
の奏効率が TS-1単独に比べて高いと報告され ているが，当院の症例のように高齢者において はいろいろな既往症を持つ場合が多く，骨髄抑 制などの副作用の出現，化学療法に対する費用 負担や当院におけるような交通といった社会的 要因によって上記の方法を選択できない場合も 多く，当院での結果からも TS-1単独による化 学療法も選択のひとつとして考慮しても良いの ではないかと考えられる吕。

結語

当院における高齢者に対する消化器がんの外 来化学療法において, 内服の $\mathrm{S}-1$ 単独療法は投 与のしやすさやコンプライアンスのみならず, 投与量や投与して方法を考慮することで副作用 の軽減, 長期継続性を可能とし, 治療効果を損 なわず比較的良好な結果を得ることができるこ とを示すことができた。現在，ベストとは決し ていえないが，交通事情などの生活環境や QOL を考えた内服の外来化学療法の選択肢の ひとつとして，当院ではガイドラインに沿った 治療のできない一部の高齢者に対しての消化器 がんの外来化学療法に位置づけられている。

\section{参 考 文 献}

1) Koizumi W, Nakahara H, Hara T, et al. S-1 plus cisplatin versus S-1 alone for the first-line treatment of advanced gastric cancer (SPIRITS trial) : a phase III trial. Lancet Oncol 2008 ; 9 : $215-221$.

2 ）豊川達也. 進行・再発大腸癌に対する $\mathrm{S}-1+$ イリ ノテカン療法と FOLFOX 4 の比較. 消化器科 $2008 ； 46(3): 286$ - 290.

3 ) 有田 淳, 酒井欣男, 藤本将史, 他. S-15投 2 休投与が著効した高齢者大腸癌再発の 1 例．癌と 化学療法 2008；35(1)：141-143.

4）土居貞幸，柳沢 哲，間狩洋一，他. TS-1の 2 週投与 1 週休薬法が著効した胃癌肝転移例の 1 症 例. 癌と化学療法 $2001 ; 28(8): 1133$-1136.

5 ) 原田勝久，野口 剛，藤原省三，他. TS-1単独 療法にて CR を得られた高齢者進行胃癌の 1 例。 癌と化学療法 $2007 ； 24(3) ： 427-430$.

6 ）久保木恭利, 水沼信之. 高齢者大腸癌の化学療 法. 癌と化学療法 $2007 ； 34(3) ： 380-386$. 


\title{
Chemotherapy for Gastrointestinal Cancer in Elderly Outpatients in Mountainous Area
}

\author{
Takeshi HASEGAWA* and Takashi MIYAKE*
}

Our hospital is located in a mountainous region of Toyota City, Aichi Prefecture. In the sphere covered by our health services, about $34 \%$ of the population is 65 years or older. The graying of the community has been progressing rapidly in the past years. Many elderly people do not have a car. Only available means of transport for them are community bus servicers operated once or twice a week. The situation makes them feel disinclined to go to take physicals or visit the hospital for health screening. When we happen to detect gastrointestinal cancer in aged persons, it is often in an advanced state or too late for surgical removal, or a relapse. For some of such cases, we consider the possibilities of chemotherapy.

Between April 2005 and June 2010, we performed laparotomies (including exploratory operations) on people aged 70 or older with gastrointestinal cancer. Of the patients excluding those with severe cognitive impairment and those in failing health, 25 patients underwent S-1 monotherapy postoperatively. The results were no less favorable than those of the cases of younger patients who had received S-monotherapy or other forms of chemotherapy for gastrointestinal cancer. Although this comparison was not adequate because the number of cases of elderly patients was too small, our hospital regards S-1 monotherapy as one of the chemotherapeutic regimens beneficial to old people with gastrointestinal cancer and helpful in maintaining the patient's qualuty of life.

*Dept. of Surgery, Asuke Hospital, Aichi, Japan 